\title{
CONTRIBUTION GUIDELINES
}

\section{Categories of Papers}

1. This journal accepts four categories; articles, opinion forum, research trends, and book reviews, in the field of the history of cultural interaction in East Asia.

2. Articles should be not more than 12,000 words, opinion forum and research trends not more than 6,000 words (including title, abstract, references, figures, tables, and line drawings), and book reviews not more than 3,000 words.

\section{Format of Papers}

1. Papers should be written in English, double-spaced on one side of A4 size or U.S. letter-size paper. Papers should be printed in a standard font, such as Times Roman. Contributors should send printed manuscripts and digital files. At the head there should appear an abstract (in English and of not more than 300 words) and about five keywords.

2. Notes (for additional discussion) should be printed at the bottom of a page as footnotes and should not be used to give references. References should be cited in the text, each with the name of the author followed by the publication date, as follows:

In his 1935 study Guo Moruo describes how . . .

As Guo Moruo (1935) mentions, ... .

... during the Qing dynasty (Guo 1935).

Use "et al." for more than three authors. The letters a, b, c, . . should be used for different works by the same author in the same year. All text references should be listed alphabetically after the notes. Please list works in the original language. An English translation may be given for titles of books and papers in foreign languages. It is not necessary to translate journal titles or publishers' names. Examples:

Yu, Ying-shih. 1967. Trade and Expansion in Han China: A Study in the Structure of Sino-Barbarian Economic Relations. Berkeley and Los Angeles: University of California Press. [Author's name follows what appears in the publication even if the romanization is not pinyin.]

Tao, De-min. 1991. "Traditional Chinese Social Ethics in Japan, 1721-1943," The Gest Library Journal 4: 2. 68-84.

Watsuji Tetsurō 和辻哲郎. 1935. Fūdo: Ningengakuteki kōsatsu 風土：人間学 的考察 (Local Cultures and Customs: Anthropological Observations). Tokyo: Iwanami Shoten.

Guo Moruo 郭沫若. 1931. Zhongguo gudai shehui yanjiu 中國古代社會研究 (Research on Premodern Chinese Society). Shanghai: Shanghai Xiandai Shuju.

3. Use the Latin script primarily. Chinese and Japanese scripts can be added after Latin transcriptions of names, technical terms, and works, especially in the bibli- 
ography. Please do this only where helpful. It is not necessary to add East Asian scripts for every Chinese or Japanese name or term. For Chinese, please use pinyin. An exception is made for Sun Yat-sen (Sun Zhongshan), Chiang Kai-shek (Jiang Jieshi), Peking University, Tsinghua University, and Taiwan names familiar in the West (e.g., Ang Lee [Li An], Taipei). For ambiguous cases, give the pinyin, followed by the common appellation: Song Jiashu (Charlie Soong), Shantou (Swatow), Guangzhou (Canton). It is usually not necessary to give Chinese characters for personal names, since these are easy to look up. For Japanese, please use the Hepburn system as modified by Kenkyūsha (e.g., shinbun, not shimbun). Indicate long vowels with a macron, and give names in their Japanese order, with family name first. For Korean, please use the the McCune-Reischauer system. Again, the family name precedes the given name. Since the romanization indicates the Hangul, it is not necessary to indicate the Hangul of Korean terms. The Chinese characters for a Korean term may be added if helpful. Examples:

The Tale of Genji (Genji monogatari 源氏物語) [a translated work]

Zhangwu zhi (長物志 Treatise on superfluous things) [an untranslated work]

collected statutes with model cases (huidian zeli 會典則例)

turtle ships (kŏbuksŏn 龜背船)

4. Tables and figures (photographs, maps, and other illustrations) may be used at the author's expense. Submit figures captions on a page or pages separate from the body of article. Special plate making is also available at the author's expense.

\section{Submission of the Manuscripts}

1. Only one copy need be supplied; JCIEA will duplicate copies for referees. Send it to Editor, Journal of Cultural Interaction in East Asia, c/o Research Institutes, Kansai University, 3-3-35 Yamate-cho, Suita-shi, Osaka 564-8660 Japan. Authors can send their electronic versions of their papers to jciea@ml.kandai.jp.

2. A manuscript must arrive no later than July 31 each year. Manuscripts are not returned.

3. The cover letter accompanying a manuscript should include the following: the name of author(s), the institution(s) to which the author(s) belong, and their titles, as well as the author's address, telephone number, fax number, and e-mail address.

\section{Copyright}

The copyright to articles and reviews published in JCIEA belongs to the journal. Manuscripts submitted should not have been published previously, circulated widely electronically, or be under consideration for publication elsewhere. We ask authors whose manuscripts or reviews have been accepted for publication not to distribute them in printed or electronic form without our permission. JCIEA readily grants permission for the reprinting of articles in anthologies or other collections and for reproducing them for classroom use. Requests for permission for such uses should be made in writing and sent to the journal at the address shown on the copyright page. 